HStud 22 (2008)1-2, 77-88 DOI: 10.15566/HStud.22.2008.1-2.6

\title{
THE HUNGARIAN FOLK DIVA: ARTIST, ADVOCATE, BUSINESSWOMAN
}

\author{
BARBARA ROSE LANGE \\ University of Houston, TX \\ USA
}

\begin{abstract}
In the 1980s, a single female performer, Márta Sebestyén, defined Hungarian folk singing. Sebestyén's voice, with the heavy ornamentation and chest timbre of the Hungarian-Transylvanian sound, became popular worldwide. Even as Sebestyén's voice was popularized via electronic dance mixes and film soundtracks, in live performances and interviews she emphasized the ethnic minority Hungarians in Transylvania who served as her musical sources. The 21 st century has seen the ascent of several young female singers in Hungary. They have taken the advocate role in a different direction, dramatizing the experiences of other underprivileged groups and of women. They face additional challenges: currently in Hungary, every sphere of artistic life, including folk music, must demonstrate economic independence. The young folk divas front their own groups and develop high concepts for their albums and performances. It remains to be seen whether their forthrightness will gain the same success as the modest image of the classic singer of the Hungarian folk revival style.
\end{abstract}

Keywords: world music, Hungarian folk song, gender, music and entrepreneurs, jazz, Transylvania, Csángó, Márta Sebestyén, Ágnes Szalóki, Bea Palya

\section{The Hungarian Folk Diva: Artist, Advocate, Businesswoman}

In opera reception the term "diva" refers first to vocal virtuosity, and second to the compelling figures behind the voices and the unique ways in which these singers dressed, acted, and lived out the dramas they played on stage. Recently the idea of the pop diva suggests the astounding vocal capabilities of such singers as Mariah Carey and indicates how singers like Madonna take an active hand in shaping their own images. The diva has become a marketing concept with concerts and albums featuring whole collections of female singing personalities in the classical, popular, jazz, and world music idioms. ${ }^{1}$ There is a significant history of fictional and real divas in Hungary, including opera characters, opera singers, nóta singers, actresses, dancers, and film stars. Folk music is a sphere for divas in Hungary because it conveys passion, meaning and value to a wide spectrum of the 
modern Hungarian public, attracts devoted fans, and helps the world sympathize with the issues of this culture of just a few million people. Conditions for folk artists in Hungary today demand that they be larger than life: folk divas fuse artistry with advocacy for underprivileged groups and business acumen.

That a performer show artistry seems self-evident. The dance house movement helped native and foreign audiences appreciate the Hungarian folksinger's parlando phrasing and ability to render the intricate ornamentation of Transylvanian folksong. Dance house instrumentalists tried to render instrumental music as faithfully as possible to the source musicians' sounds, and solo singers from the dance house environment tried to do the same. The communal dance house atmosphere produced a dedicated audience for folksong when it fostered wholehearted participatory singing and appreciation of the texts of songs. Those who wanted to sing as soloists had to dissect and study field recordings as intricately as dance house instrumentalists, and counted their experiences in the field as equally crucial. Rhythm, timbre, harmony, ornamentation, accents, and dialect differed within the microregions of Transylvania, from fiddler to fiddler and singer to singer. It could be argued that the details of singing were even more subtle than revival instrumental music, simply because there could be more singers than instrumentalists in the source villages. Like the dance house bands, each solo singer of Hungarian folk songs developed a unique stylistic and genre profile.

Burton Peretti has described how jazz in the US became "formalized" as critics, pedagogues, and musicologists incorporated jazz into the academy. ${ }^{2}$ Even though Bartók, Ortutay, and others assigned a high aesthetic value to the folksong, revival musicians in Hungary experience themselves as in a long struggle to formalize folk music and thereby prove that it is equivalent aesthetically to Hungary's art music. The dance house proponents participated with source musicians and analyzed music and dance for the purpose of performance, whereas Hungary's research institutions developed theories of folk music according to a European academic model. Thus the dance house proponents worked within alternative institutions for research and study, such as the Institute for Folk Culture. In the competitive atmosphere since 1989, even after they established the House of Traditions, the revivalists experienced how classical music has a privileged spot in Hungarian public funding, academia, public broadcasting, and performance venues. László Kelemen wrote in the music magazine Fidelio,

Bartók delved in the deepest way possible into the mine of Carpathian Basin folk music... in our superficialized world, except for a few exceptions, I do not see that purpose fulfilled... [in the dance house movement]... we rank the cultivators who are steeped in the folk music of the Carpathian Basin next to the cultivators of high art, because they share goals and means. ${ }^{3}$ 
Dance house advocates did partly formalize folk music by establishing a canon. In the 1980s, when the release of both revivalist and source recordings expanded, audiences came to know and admire source singers from Transylvania and later those from the Moldavian region just to the east of the Carpathian mountains. As Lydia Goehr has argued, the reception process elevates music from a life activity to the status of a work. ${ }^{4}$ Dance house musicians and audiences came to love specific songs for their texts, their unique modes and ornamentation, or their association with ethnic minority regions for which Hungarians have particular sympathy.

Advocacy activity stretches back to before the time of Bartók. Concerning oneself with folk music meant concerning oneself with the disadvantaged or oppressed state of the people who originally performed that music. Bringing the music to an audience meant bringing the disadvantaged conditions of the source musicians and the villages in which they lived to the attention of the public. Folk revivalists of the 1970s dance house movement were therefore advocates for the purveyors of the musical sounds and peasant environments supporting those sounds, especially within the rustic province of Transylvania, lying outside the borders of Hungary. This advocacy came out of direct involvement. László Kürti argues that dance house participants, having lost their own peasant roots due to the rapid industrial development of Hungary under socialism, tried to reconnect elements of society that had become atomized, such as village with city, elderly with young, the educated with peasants, and region with region across national borders, especially via musical tourism to areas in Transylvania in which members of the Hungarian minority lived. ${ }^{5}$ The revivalists, taking their cue from the sensitive work of Bartók, László Lajtha, and the dance scholar György Martin, treated the source musicians as equals. The art historian and urban-culture critic Ferenc Bodor wrote in Nomad Generation, a photo-essay on the Hungarian folk revival,

\footnotetext{
for me, a layperson, the simultaneous indifference and officiousness of the people who handled the peasant musicians was stupefying. Old men put on the stage, torn from their environment, made victims of sugary reporters, exploited by collectors, withstood everything helplessly... and how many decades passed until the village musicians and singers met with people who did not need this music merely for scientific works and studies, but who also wanted to play this music, who didn't consider the musician and singer simply as a source of data, but also as partner? ${ }^{6}$
}

From the beginning of their activity, dance house proponents also followed a model of "positive discrimination" in highlighting the music and dance of Romanian, south Slavic, and Roma ethnic minorities within the borders of Hungary. ${ }^{7}$ From the 1990s onwards, a general style of advocacy continued to explore the model of Hungary as a multiethnic society, including Roma and Jews. As the 
country has become aggressively capitalist, concern for other people in an unequal position (the poor, children, women, the elderly) has emerged as a major theme.

The business end of folk music has been especially apparent in the 21 st century. Angela McRobbie has pointed out that European unification and the equalizing of the markets across borders may have strengthened the hand of recording companies (at least until the collapse of the compact disc medium). The notion that European unification freed individual musicians to be flexible with their tour and contract arrangements actually obscured the fact that they had almost no leverage as individuals with the expanded music businesses. ${ }^{8}$ Hungary's market orientation is harsh, but it has stimulated creativity. In a 1999 essay the sociologist Erzsébet Szalai analyzed Hungarian entrepreneurs and found that the successful ones took risks, clearly foresaw alternatives, maintained personal connections with those in power, and kept a core of symbolic capital intact. ${ }^{9}$ Hungary's folk divas are entrepreneurs; they have taken the risk of establishing individual careers separate from known instrumental folk ensembles. Nonetheless, they depend on their personal connections with those same instrumentalists because they make sonic innovations. In their experiments they utilize a variety of arranging styles and depend on those instrumentalists to create the arrangements. They also try to maintain connections with the powerful Hungarian media. Critical reviews are a sparse component of the current Hungarian press coverage, but the singers are able to arrange interviews. These interviews cover issues of interest for the audiences of a given newspaper or television or radio channel, thus helping to increase the singer's exposure. The divas build on the symbolic capital of a voice skilled in the rhythmic and ornamental nuances and variations in timbre of Hungarian folk music.

Divas contribute to the stage performance element of the dance house movement, although the teaching and participation aspects of dance house activity have shaped their artistic development. They have varied repertoires and vocal styles, but all keep a core of Hungarian folksongs. The singers have undergone a journeywoman period during which they were members of touring performance groups and/or bands staging weekly dance house events. They thereby became competent in one or more of the canonic regional and ethnic-minority repertoires associated with dance house activity. Another key element, very unusual for women in Hungarian society, is that these singers are independent artists. This has meant a loss to the ensembles they served as journeywomen, and audiences fondly remember the periods and recordings of these ensembles when the divas were members. To stand as soloist is a major choice for them as entrepreneurs, and means innovative projects and artistic directions. As part of their larger-than-life quality, these singers enact fictional roles. Some singers, like the original instrumentalists of the dance house movement, set works of the noted Hungarian poets 
to music in the genre referred to as "sung poetry." Several have engaged in musical meta-commentary with interpretations of folk music in jazz, classical, rock, or electronic idioms. The Hungarian state and other musical organizations have recognized these singers with many prizes.

Márta Sebestyén, the most famous Hungarian folksinger, has combined artistry with advocacy throughout her career. Sebestyén is like other revivalists in that she learned musical genres and styles from an etic standpoint. Sebestyén did not participate in the analytical or teaching arms of dance house. She taped, transcribed, and picked up songs from source musicians by ear. She even worked up convincing performances solely from manuscript notations. Sebestyén emphasizes experience and passion over other styles of musical learning. She stated to the British writer Ian Anderson,

I couldn't explain to anyone how to sing. How should you feel when you sing. I can only say, 'Come and hear these old people playing,' then you get impressed and I'm sure you will have the feeling for it. ${ }^{10}$

The Hungarian word for "impression," benyomás, connotes a literal experience and not intellectual evaluation. Sebestyén stresses that she was drawn to the sounds of Transylvanian source singers from the very first moment she heard a field recording as a teenager. Even in describing her own artistry, Sebestyén gives credit to the source culture. She states,

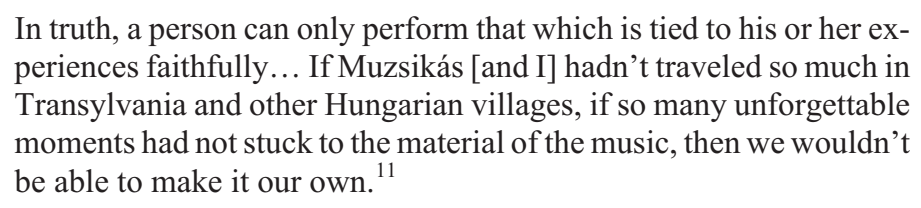

The broadest segment of the Hungarian public became fans of Sebestyén's voice when she sang the role of Réka, the peace-loving Christian daughter of the pagan leader Koppány in the 1984 film István, a király (Stephen the King) about Saint Stephen, the first king of Hungary and a Christian. In the late 1980s, when Muzsikás and Sebestyén released The Prisoner's Song on Hannibal Records, British reviewers and audiences loved the arranged song Repülj, madár, repülj (Fly, Bird, Fly) because it sounded like progressive-folk fusion with Irish music. ${ }^{12}$ This song illustrates that Sebestyén had mastered the ornamented Hungarian folksong style. She recreated it only from a transcription. Hungarians valued the source locale of this song, Armăşeni (Csíkmenaság), a village on the eastern edge of the Székely Land in Transylvania, historically an important territory for Hungarian speakers.

Sebestyén had a second burst of stardom when the French electronic-music duo Deep Forest featured her voice on the 1995 album Boheme. ${ }^{13}$ Deep Forest 
sampled and electronically mixed a performance by Sebestyén for Marta's song, which sold more than four million copies, and the duo won a Grammy for the album. Deep Forest was legally able to sample a recording by Sebestyén, having purchased the rights from the Belgian firm Fonti Musicali. But Sebestyén has stated that she is ambivalent about the artistic results: "When I first heard it, I was horrified. I found it strange that I only learned about it afterwards... so I had very mixed feelings. On the other hand, by means of this Hungarian folk music reached many millions of people." 14 Sebestyén complained that the worst part of having her voice mixed in the Boheme project was that the music elüzletiesedett (had been commercialized away). Sebestyén's voice, in a song that she learned under harsh fieldwork conditions, became even more well-known when it was featured on the soundtrack for the film The English Patient.

In addition to the many arrangements of folk songs of which Sebestyén has thus been a part, she has maintained a compelling on-stage image, restricted yet concentrated and forceful. She wears elements of folk costume, including vests, jewelry with folk motifs, and blouses, and often pulls her hair back severely like a peasant woman. In her appearances with the band Muzsikás she started at the back of the stage, moving in modified female dance steps, and she continued these movements while singing. This image parallels the way that Sebestyén emphasizes the value of the rural source musicians living outside Hungary. Sebestyén's activities since 2006 have included a concert tour of Transylvania and a series of interviews. In these interviews, Sebestyén chatted with equal energy about her children and about the high pinnacle of her success, signified by the fact that she received fan letters from European royalty.

Other folksingers in Hungary must take Sebestyén's successes and her stage demeanor into account. In fact there is a twenty-five year gap between Sebestyén and the current generation of female folksingers. The first female folksingers to succeed her made a mark in teaching, not performance. By the mid-2000s, however, at least five young folksingers had emerged, all cultivating diva images. Sebestyén's success enabled this by changing the balance of power within folk ensembles. Young female folk singers are now able to have independent careers and receive quite respectful treatment from the instrumental players with whom they work.

Ágnes Szalóki, aged 30, has made a strong mark on Hungarian concert life by creating jazz interpretations of folk music, by including Roma music in her programs, and by appearing as a singer with Hungarian folk bands. An urbanite, Szalóki was not raised with folk traditions in the home, but began performing this music in public at an early age. Szalóki commented that she first fell in love with Hungarian folk music as a child at the Óbuda folk music school in Budapest. This program had been in operation since the 1970s, when arranged folk music was the norm. After the end of socialism the dance house musicians inaugurated a system 
of teaching their knowledge of folk music based on village practice. ${ }^{15}$ The Óbuda school, along with dance house evenings, helped create a canon of dance house substyles that participants considered the most important, among them the music of the Moldavian Csángós, an ethnic group that lives to the east of Transylvania. Playing music of the Csángós symbolically casts light upon their situation. They faced extremely strong assimilationist pressures to the point that although they retained Roman Catholicism as a religion, in language, music, and folk arts they blended with Romanian culture. ${ }^{16}$ Szalóki learned to play the Csángó percussion cello ütögardon at the Óbuda school, and comments that she found a pressure-free atmosphere there that contrasted with the seriousness of academic school.

Szalóki started performing with Hungarian stage folk groups in her late teens. She began singing with the veteran dance house band Ökrös and still works with the group regularly. In addition, she worked for several years as a singer with Besh O Drom. This band gained international popularity by creating fast arrangements of music in a Balkan Roma rather than a Hungarian folk style. Szalóki then decided to become an independent musician, combining solo projects with bids from Ökrös and the jazz player Béla Szakcsi Lakatos to serve as their vocalist. Szalóki now performs revivalist folk music, fusion sounds, and jazz. She has achieved consistent successes in the meta-commentary of jazz-folk. She prepared and released solo CDs in 2005 and 2006. Both were jazz-based projects, and both received national prizes. Szalóki's projects illustrate how entrepreneurialism can combine with aesthetic elevation and a larger vision of humanity represented, in the view of many Hungarians, by folk music. Her solo projects, while recognized for their artistry, are at the same time business ventures. Szalóki musically symbolizes that Roma and Hungarian styles of folk music in Hungary, and by implication the two peoples, mix and coexist. At the same time, by interpreting this music in jazz and in well-known popular idioms, she illustrates the cosmopolitan sensibility of modern Hungary.

Szalóki's 2006 children's CD Cipity Lörinc illustrates this combination. Children's concerts blend artistic, advocate, and business purposes quite harmoniously. Children's music is thriving commercially in Hungary; Szalóki has been in demand for years all over the country and in neighboring Hungarian-speaking areas, staging her children's concert about once a month. Children's concerts featuring folk music are well accepted and well attended. CDs of children's music performed by folk groups sell briskly and are well stocked in all record stores. There is also at least a thirty-five year history of creating fusion sounds in children's music, especially in the genre of sung poetry. Cipity Lörinc intersperses sung poetry with Roma and Hungarian folk texts and melodies. These are set to reggae, bossa nova, Cuban, jazz-rock, Township jive, and other jazz accompaniments. In 2007 it won the title "Children's Album of the Year" from Fonogram, the organization of the Hungarian Association of Record Publishers (MAHASZ). For Pergetö, 
Szalóki selected a Hungarian folksong text and then set it to a Transylvanian Roma melody. Szalóki is Roma but not a Romany speaker. Following folk revivalist practice, she learned this melody from an ethnographic collection compiled by the Roma poet and painter Károly Bari. The jazz setting connotes a high art concept to Hungarians. Guitarist Dávid Lamm made the instrumental arrangement of chords and instrumentation. The tempo is sped up and the vocal tone is light, making Szalóki's pergetés or vocables into virtuosic scatting. Lamm's stopped offbeat or esztam and its added sixth and seventh chords evokes Django Reinhardt's Gypsy-swing style, but his articulations are much drier and lighter. ${ }^{17}$ In live performance, Szalóki creates a focused rapport with the audience of small children. Before each number Szalóki encourages the children to do an activity. She has children make gestures indicating animals and natural landmarks, thus grounding the folksong motifs of flying birds, hills, and valleys in their bodies. Szalóki and her musicians fuse different varieties of folk music and lighten the mood via jazz, while still educating the children.

Szalóki has assumed the role of one of Hungary's best-loved divas, performing the songs of the 1940s film star Katalin Karády. Karády was famous for her over-the-top roles that dramatize failed love, fitful passion, and even rebellious female independence. Here, the canonic text is not the field recording, but Karády's commercial audio and film material, with theater orchestral accompaniment and a distinctive singing style. Karády's voice embodied a femme fatale ethos, legendary and unusual among Hungarian actresses for its low pitch, smoky tone, and exaggerated pitch glides. Interest in Karády revived in the late 1970s, and the social psychologist Ágnes Hankiss argued that this was because she was so kitschy. An interest in kitschiness was actually dissident because it was purely fun, without the serious and progressive purpose that socialism required the arts to demonstrate. ${ }^{18}$ Audiences today enjoy and contribute to Szalóki's act. A crowd of university and older couples attended her 2007 performance of Karády songs at the West Balkan nightspot in Budapest. Szalóki entered in a black dress and sat on a high stool and her musicians, dressed much more informally in jeans, sat behind her. As Szalóki sang (and chatted with the audience in an ironic tone about how tight her dress was, how high the stool and made other arch meta-commentary), the camera shutters of at least four photographers clicked continuously. Szalóki plays with elements of Karády's hallmark style, choosing a higher tessitura, singing more melodically, and utilizing pitch glides much more sparsely than Karády. The accompaniment is supplied by a small number of jazz musicians with a great deal of variety, including rock arrangements.

Beáta Palya is another young singer who illustrates a combination of artistry and advocacy. Palya, in her early thirties, officially represented Hungary at the opening concert of the 2004 Olympics, as the Ambassador of Equal Opportunities in 2007, and as a Global Ambassador of Hungarian Culture in 2008. In her teens 
Palya established herself in Budapest as part of the Zurgó ensemble formed around the weekly dance house held in Marczibányi square in Budapest and specializing in the music of the Csángós. In the 1990s she began experimenting with improvisation in Laocoon, a multidisciplinary arts group spearheaded by the composer Samu Gryllus. Gryllus is from the second generation of the folk revival. He is the son of the 1970s folk musician Dániel Gryllus. In 2006 Palya and Samu Gryllus created a CD project in the sung poetry genre. They set Sándor Weöres's cycle Psyché to music. This famously difficult cycle, completed in 1972, is a collection of poetry by a single fictional author named Psyché or Erzsébet Lónyay, who supposedly lived at the turn of the nineteenth century. In Biedermayer syntax, the poems relate her harsh fate and passions as a woman. Palya has often commented in interviews that she felt a parallel between herself and the passion, sensuality, and mixed-ethnic background of the Lónyay character (Palya is one-fourth Roma and Lónyay is half Roma):

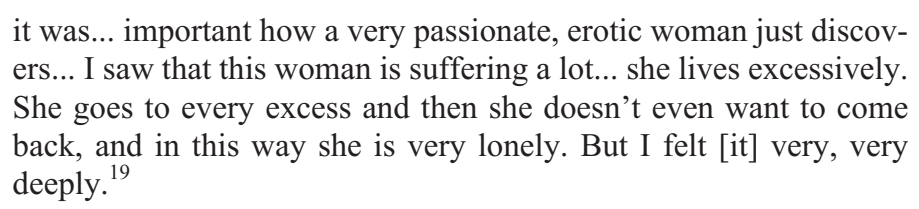

Presenting the poetic cycle in performance, Palya dramatizes the creative tension in Lónyay, singing in a sensitive and tender vocal style much admired in Hungarian folk music, segueing into the explosive energy of Romany dance music and shifting tonality and rhythm for the most dramatic sections of the cycle.

Palya and Gryllus's setting of the Psyché cycle did not have many reverberations in the high-arts sphere. The CD prompted few reviews (although it did receive many publicity announcements) and the group performed the entire cycle only a few times, in Vienna in 2006 and several times in spring 2008. Conjunctly with her cameo appearance as a bar singer in an erotic scene in Tony Gatlif's 2007 film Transylvania, Psyché enhanced Palya's commercial image. She explained to Zoltán Végső of the literary periodical Élet és Irodalom (Life and Literature) that her setting of this cycle had made her something of a sex symbol and that she'd been getting extremely passionate fan mail. ${ }^{20}$

In the early 2000s Palya sang Hungarian folk songs, Hungarian Roma music, and also Bulgarian (especially Thracian), Persian, Indian, and other music. She varied her vocal tone according to each style, rendered the ornaments in detail, and had clear diction. In 2007, Palya concertized with a small group of accompanying instrumentalists under her own name and with other European artists. She had a CD release pending with the French label Naive, and in the music for that $\mathrm{CD}$ she further explored and improvised on vocal timbres, pitches, and ornaments. In several 2007 performances she played the role of St. Elizabeth, the thir- 
teenth-century Hungarian princess who was canonized for dedicating herself to care for the sick. In that role she sang almost no texts. A November 2007 dramatization of the St. Elizabeth legend was staged in the Budapest cathedral of Saint Anthony of Padua. Veiled and dressed in white robes at this performance, Palya paced through the resonant cathedral space, making vocalizations that resembled Indian dhrupad meditations on pitch and mood, but adding dynamics, timbre variations, melismas, and extra pitch glides. Palya has thus recreated historical and fictional Hungarian female figures covering a spectrum of passion, artistic aspiration, and humanism.

The extremely demanding conditions for folk music performance in Hungary elicit a divas' response. Building on the success of Márta Sebestyén, younger folk singers have stood independently, devising artistic projects together with trusted groups of instrumental musicians. They add to their own stature by reinterpreting important female figures and divas of the past, whether fictional or real. Audiences interpret this once again, appreciating dimensions that are relevant to the contemporary setting, in which sexuality is frank, poverty is shocking, humanism is officially embraced, and each person must make a place for himself or herself in the vigorously competitive artistic environment.

\section{Acknowledgments}

This article is based on field research conducted in Hungary from 1990-1992 and 2006-2007 with the support of grants from Fulbright and the International Research and Exchanges Board in 1990-1992, Small Grants from the University of Houston in 2006 and 2007, and the Joint Austrian-Hungarian Fulbright Research Fellowship in 2007. None of the organizations is responsible for the views expressed here. The author gratefully acknowledges the assistance of many musicians, in particular the generous friendship of the Cserepes family.

\section{Notes}

1 Leonardi and Pope note that female singers of both pop and classical genres take risks with their voices, experiment with gender roles, and attract groups of fans devoted to their dramatic musical personalities. See Susan J. Leonardi and Rebecca A. Pope, The Diva's Mouth (New Brunswick NJ: Rutgers U. Press, 1996).

2 Burton Peretti, Jazz in American Culture (Chicago: Ivan R. Dee, 1997).

3 László Kelemen, "VilágDivat," Fidelio, January 2005, 3. In 2007 folk song achieved another step in formalization when it was established as a component of the curriculum of the Liszt Conservatory. A musician who had been active in dance house, András Jánosi, was hired to teach the subject. 
4 Lydia Goehr, The Imaginary Museum of Musical Works (London: Oxford University Press, 1992).

5 László Kürti, The Remote Borderland: Transylvania in the Hungarian Imagination (Albany: State University of New York Press, 2001), 150-159. The dance house participants continued a significant tradition of advocating for the rural poor in Hungary.

6 Ferenc Bodor, "Peasant Musicians," in Nomád nemzedék, ed. Ferenc Bodor (Budapest: Népművelési Intézet, 1981), 17. My translation.

7 Kürti, The Remote Borderland, 145.

8 Angela McRobbie, “'Everyone is Creative'. Artists as Pioneers of the New Economy?" LabforCulture.org BeCreative Text Archive (2004), http://www.k3000.ch/becreative /texts/text 5.html (accessed June 26, 2006). Hungarians and other Central Europeans continue to generate and support a market in compact discs, creating mementos with beautifully photographed and printed CD covers and oversize boxes, all with complete lyrics.

9 Erzsébet Szalai, "Kaleidoscope: How do Large Hungarian Companies, Company Executives and Entrepreneurs Innovate?" in Post-Socialism and Globalization (Budapest: Új Mandátum Könyvkiadó, 1999), 171-200.

10 "Marta to the Cause: Ian Anderson Meets Marta Sebestyén and Peter Eri from Muzsikás," Folk Roots, December 1987, 35.

11 Veronika Eszter Kiss, "Nem tudnék éneklés nélkül élni. Sebestyén Márta a hitelességről és kedves emlékeiről," Magyar Nemzet, December 25, 2003. My translation.

12 At the time British critics commented much less on the unaccompanied, haunting Szerelem, szerelem (Love, Love) and were somewhat confused by the aggressive style of Hidegen fújnak a szelek (Cold Winds Are Blowing). In the late 1980s political repression inhibited Muzsikás and other dance house proponents from explaining the protest subtext of the latter song.

13 Deep Forest had bought the rights to African field recordings and sampled them for their 1992 album Deep Forest, causing an ethical debate in ethnomusicology and in the popular music world. See Stephen Feld, "Pygmy POP: A Genealogy of Schizophonic Mimesis," Yearbook for Traditional Music 28 (1996), 1-35.

14 Veronika Eszter Kiss, "Nem tudnék éneklés nélkül élni." The remixing of Roma singers on Boheme has caused major ethical controversies to this day. The heirs of one Roma singer, Károly Rostás, have sued to receive additional compensation and their efforts were tracked in a documentary film that symbolized the divide in wealth and privilege between Western and Eastern Europe as well as the unequal position of Roma in East Central European societies. See Tibor Borzák, "Ellopták apám hangját!” Szabad Föld Online, May 12, 2006, http://www. szabadfold.hu/cikk.php?cikk=6152 (accessed June 3, 2008).

15 Óbudai Népzenei Iskola, "A magyar zenei anyanyelv iskolája. Bemutatkozás," http://www. nepzeneiskola.hu/ (accessed June 10, 2008). My translation.

16 Starting in the early 1990s Csángó music became quite popular with Hungarian dance house participants. There was a cultural infusion as Csángó young people started attending gymnasium in Budapest. Csángó line dance movements were much easier than the complex vocabulary of the dance house movement's popular partner and male dances from Transylvania.

17 Hungarian players, because of their long experience with the esztam upbeat, can give very subtle renditions of bossa nova.

18 Ágnes Hankiss, "Karády Katalin - 1979/80," in Kötéltánc (Budapest: Magvető, 1984), 286316.

19 Interview with author, Budapest, May 6, 2006.

20 Zoltán Végső, "Meztelen vallomás," Élet és Irodalom 51/25 (June 22, 2007), http://www. es.hu/pd/display.asp?channel=INTERJU0725\&article=2007-0624-2005-56SSDH (accessed December 15, 2007). My translation. 


\section{References}

Bankó, András. Muzsikás évtizedek (Budapest: Kós Károly Alapítvány, 1994).

Bodor, Ferenc. "Peasant Musicians," in Nomád nemzedék, ed. Ferenc Bodor (Budapest: Népmúvelési Intézet ,1981), 15-21.

Feld, Stephen. "Pygmy POP: A Genealogy of Schizophonic Mimesis." Yearbook for Traditional Music 28 (1996), 1-35.

Goehr, Lydia. The Imaginary Museum of Musical Works (London: Oxford, 1992).

Hankiss, Ágnes. “Karády Katalin - 1979/80.” Kötéltánc (Budapest: Magvető, 1984), 286-316.

Kelemen, László. "VilágDivat." Fidelio (January 2005).

Kürti, László. The Remote Borderland: Transylvania in the Hungarian Imagination (Albany: State University of New York Press), 2001.

Leonardi, Susan J. - Rebecca A. Pope. The Diva's Mouth (New Brunswick, NJ: Rutgers University Press, 1996).

"Marta to the Cause: Ian Anderson Meets Marta Sebestyén and Peter Eri from Muzsikás." Folk Roots (December 1987), 34-37, 39.

McRobbie, Angela. "Everyone is Creative'. Artists as Pioneers of the New Economy?" LabforCulture.org BeCreative Text Archive, 2004. http:/www.k3000.ch/becreative/ texts/text_5.html (accessed June 26, 2006).

Óbudai Népzenei Iskola. "A magyar zenei anyanyelv iskolája. Bemutatkozás.” http://www. nepzeneiskola.hu/ (accessed June 10, 2008).

Peretti, Burton. Jazz in American Culture (Chicago: Ivan R. Dee, 1997).

Szalai, Erzsébet. "Kaleidoscope: How Do Large Hungarian Companies, Company Executives and Entrepreneurs Innovate?" in Post-Socialism and Globalization (Budapest: Új Mandátum Könyvkiadó, 1999), 171-200.

Végső, Zoltán. “Meztelen vallomás.” Élet és Irodalom 51/25 (June 22, 2007). http://www.es.hu/ $\mathrm{pd}$ /display.asp?channel=INTERJU0725\&article=2007-0624-2005-56SSDH (accessed December 15, 2007). 